\title{
Soluble Low Affinity Fc Receptors for IgE in the Serum of Allergic and Nonallergic Children
}

\author{
KWANG-MYONG KIM, MITSUHIKO NANBU, YOSHITAKA IWAI, MAYUMI TANAKA, \\ JUNJI YODOI, MITSUFUMI MAYUMI, AND HARUKI MIKAWA \\ Department of Pediatrics, and Institute for Immunology [J.Y.], Faculty of Medicine, Kyoto University, \\ Kyoto, Japan
}

\begin{abstract}
IgE-binding factors are thought to have regulatory activity in in vitro IgE synthesis. To obtain evidence of the participation of IgE-binding factors in in vivo IgE synthesis, the serum level of low affinity $\mathrm{Fc}$ receptors for IgE (sFceRII) (IgE-BFs) was examined in 41 nonallergic children and in 37 allergic children whose serum IgE levels were significantly higher than those of nonallergic children. The serum level of $\mathbf{s F} \epsilon \mathrm{RII}$ showed a marked age-dependent variation. It was highest in infants and then decreased gradually with age. The serum level of $s F c \in R I I$ in allergic children was significantly higher than that of nonallergic children in early childhood $(1128.0 \pm 323.8$ vs $777.3 \pm$ $227.0 \mathrm{pg} / \mathrm{ml}, p<0.01$ in infants $(<1 \mathrm{y})$ and $851.8 \pm 270.0$ vs $579.4 \pm 197.1 \mathrm{pg} / \mathrm{ml}, p<0.05$ in children aged $1-2 \mathrm{y}$ ) but not in older children (3-15 y). Three allergic infants $(<1$ y) with serum $\mathrm{sFc} \in \mathrm{RII}$ levels higher than the mean + $1 \mathrm{SD}(1451.8 \mathrm{pg} / \mathrm{ml})$ of all allergic infants $(<1 \mathrm{y})$ had serum IgE levels (geometric mean $125.9 \mathrm{IU} / \mathrm{ml}$ ) significantly higher than the other seven allergic infants $(<1 \mathrm{y})$ (geometric mean $5.6 \mathrm{IU} / \mathrm{ml}, p<0.05$ ). A close positive correlation between the serum level of $s F c \in R I I$ and the absolute number of $\mathrm{Fc} \in \mathrm{RII}(+)$ peripheral blood lymphocytes was observed (Spearman's rank correlation coefficient $=0.79, p<0.001$ in 27 allergic and Spearman's rank correlation coefficient $=0.72, p<0.001$ in 19 nonallergic children). In conclusion, serum $s F c \in R I I$ may be derived mainly from FceRII(+) lymphocytes, and may have relationship to the increased production of IgE in early childhood (0-2 y). (Pediatr Res 26: 49-53, 1989)
\end{abstract}

\section{Abbreviations}

Fc $\epsilon$ RII, low affinity $\mathrm{Fc}$ receptors for $\operatorname{IgE}$

IgE-BF, IgE-binding factor

MNC, mononuclear cells

RAST, radioallergosorbent test

rs, Spearman's rank correlation coefficient

sFceRII, soluble form of $F c \in R I I$

It has been demonstrated in rodents that $\operatorname{IgE}$ production is regulated by IgE-BF $(1-3)$. IgE-BF are glycoprotein molecules with affinity for $\operatorname{IgE}(4,5)$ consisting of two functionally different components: one enhances IgE synthesis (IgE-potentiating factor) (2), and the other inhibits it (IgE-suppressive factor) (3). The

Received September 16, 1988; accepted March 7, 1989.

Correspondence Kwang-Myong Kim, M.D., Department of Pediatrics, Faculty of Medicine, Kyoto University, Shogoinkawahara-cho 53, Sakyo-ku, Kyoto 606, Japan.

Supported by grants from the Ministry of Health and Welfare, and the Ministry of Education, Science and Culture, Japan. former is produced by $\mathrm{Fc} \epsilon \mathrm{RII}(+) \mathrm{T}$ lymphocytes, and the latter

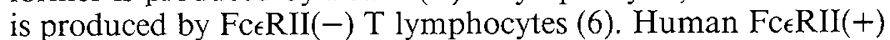
T lymphocytes can secrete IgE-potentiating factor (7-10). Recently, Fc $\epsilon$ RII(+) B lymphocytes, which are more numerous than FceRII(+) T lymphocytes $(11,12)$, have also been shown to be capable of producing IgE-potentiating factor (13-15). Thus, Fc $\in \operatorname{RII}(+)$ B lymphocytes, as well as FceRII(+) T lymphocytes, appear to be involved in the regulation of $\operatorname{lgE}$ synthesis.

With the use of $F c \in R I I(+)$ human B lymphoblastoid cell lines (RPMI1788, RPMI8866), several anti-Fc $\epsilon$ RII $m A b$ have been produced (16-19). It is now easy to detect not only FceRII, but also IgE-BF because of their common antigenic determinants to FceRII $(20,21)$. The production of the mAb was followed by the determination of the gene structure of FceRII (22-24), which in turn enabled its more precise molecular analysis. Fc $\epsilon$ RII was demonstrated to be the same molecule as the CD23 Ag $(19,25)$. The IgE-BF obtained from the supernatants of Fc $\epsilon$ RII $(+) \mathrm{T}$ and $B$ cell lines was demonstrated to be the soluble form of $F c \in R I I$ (sFceRII) released by cleavage of the polypeptide chain $(15,26$, 27).

The serum IgE level is often increased in allergic individuals (28). The proportion of $F c \in R I I(+)$ lymphocytes has been shown to be increased in allergic patients and in those with nonallergic hyper-IgE conditions (29-31). This suggests that FceRII(+) lymphocytes participate in the regulation of in vivo IgE synthesis by the production of $s F c \in R I I$. If $s F c \in R I I$ actually plays a role in the in vivo synthesis of $\mathrm{IgE}$, its serum level should be significantly different between allergic and nonallergic individuals. With this assumption, we investigated the serum level of $s F c \in R I I$ in allergic and nonallergic children because the elevation of the percentage of $\mathrm{Fc} \epsilon \mathrm{RII}(+)$ lymphocytes, which release $s F c \in R I I$, is detected much more easily in allergic children than in allergic adults (31).

\section{MATERIALS AND METHODS}

Donors. Allergic disorders were diagnosed when children with typical symptoms showed positive results in RAST or skin tests and/or elevated serum IgE levels higher than the geometric mean +1 SD of those of nonallergic children in this study. In actual practice these levels were set at $10 \mathrm{IU} / \mathrm{ml}$ in infants, $100 \mathrm{IU} / \mathrm{ml}$ in 1 - to 2 -y-old children and $400 \mathrm{IU} / \mathrm{ml}$ in older children $(3-15$ y).

The allergic group consisted of 37 children ( 25 males and 12 females); 15 had atopic dermatitis, 14 had bronchial asthma, and 8 had both. Among them, $33(89.1 \%)$ had a positive family history of allergy, and $28(75.7 \%)$ had both positive RAST scores and elevated serum IgE. Patients receiving continuous medication with systemic corticosteroids, which have been reported to inhibit Fc $\epsilon$ RII expression $(29,32,33)$, were not included. The nonallergic group consisted of 41 children $(23$ males and 18 females); none had allergic, immunologic, or hematologic problems. Between March 1987 and January 1988, peripheral blood 
samples were obtained at the time of the child's routine blood examinations after informed consent had been obtained from their parents. Eleven cord blood samples were obtained at fullterm, uneventful deliveries. Blood of normal and allergic adults was drawn from volunteers in our laboratory. Heparinized blood samples for the examination of the percentage of $F_{C} \in \mathrm{RII}(+)$ lymphocytes were used immediately, and serum samples for $\mathrm{sFc} \epsilon \mathrm{RII}$ determination were stored at $-40^{\circ} \mathrm{C}$ until the examination. Under this condition, the value of serum $s F c \in R$ II was stable for at least $1 \mathrm{y}$.

Measurement of serum IgE levels. Serum IgE levels were examined by Pharmacia IgE RIA kits (Pharmacia Fine Chemicals, Uppsala, Sweden), which were generously provided by Shionogi \& Company Ltd., Osaka, Japan. The measurable range is $10-2,000 \mathrm{IU} / \mathrm{ml}$ with the standard procedure, and 1 to $40 \mathrm{IU} /$ $\mathrm{ml}$ with the high sensitivity procedure.

Determination of serum $S F C \in R I I$. $s F c \in R I I$ was measured by the solid phase sandwich ELISA method described previously (15). Two mouse anti-human Fc $\epsilon$ RII $m A b$, which recognized different epitopes, were applied to the assay. One was the H107 antibody (18) and the other was the mAb 176 antibody which was kindly provided by Dr. G. Delespesse of the University of Montreal, Quebec, Canada (16). Both the H107 and Mab176 antibodies are demonstrated to react with $\mathrm{sFc} \epsilon \mathrm{RII}$ derived from $\mathrm{Fc} \in \mathrm{RII}(+)$ $\mathrm{T}$ and $\mathrm{B}$ lymphocytes $(15,27)$. This assay system is also able to detect $\mathrm{sFc} \epsilon \mathrm{RII}$ derived from a human monoblastic cell line U937 (15) and a human eosinoleukemic cell line EoL (M. Hosoda and J. Yodoi, unpublished data).

Briefly, $2 \mu \mathrm{g} / \mathrm{ml}$ of mAb176 antibody in $\mathrm{NaOH}-\mathrm{NaHCO}_{3}$ solution ( $\mathrm{pH}$ 9.0) was delivered into a polystyrene microplate (Immuno plate I, Nunc, Roskilde, Denmark) in a volume of 50 $\mu \mathrm{l} /$ well and incubated overnight at $4^{\circ} \mathrm{C}$. Residual binding sites of the solid phase were blocked by $150 \mu \mathrm{l}$ of ELISA solution (10 $\mathrm{mM}$ PBS containing $2 \% \mathrm{BSA}$ and $0.05 \%$ Tween 20 ) in each well. After incubation overnight at $4^{\circ} \mathrm{C}$, a $50 \mu \mathrm{l}$ sample was placed in each well in triplicate and incubated overnight at $4^{\circ} \mathrm{C}$. Then, $50 \mu$ l of alkaline phosphatase VII-S (Sigma Chemical Co., St. Louis, MO) coupled H107 antibody in ELISA solution (0.4 $\mu \mathrm{g} / \mathrm{ml}$ ) was put into each well and incubated for $4 \mathrm{~h}$ at $4^{\circ} \mathrm{C}$. Finally, $100 \mu \mathrm{l}$ of enzyme substrate solution (1 tablet of phosphatase substrate (Sigma) per $5 \mathrm{ml}$ substrate buffer) was placed in each well. Then 1 liter of substrate buffer, $\mathrm{pH} \mathrm{9.8,} \mathrm{contained}$ $97 \mathrm{ml}$ of diethanolamine, $100 \mathrm{mg}$ of $\mathrm{MgCl}_{2} \cdot 6 \mathrm{H}_{2} \mathrm{O}$ and $200 \mathrm{mg}$ of $\mathrm{NaN}_{3}$. Plates were washed vigorously five times with washing solution (PBS containing 0.05\% Tween 20) after the completion of each incubation.

The enzyme activity bound to the solid phase was determined by reading the absorbance at a wave-length of $405 \mathrm{~nm}$ with an automated photometer (MTP12, Corona Electric Co Ltd, Ibaragi, Japan). Standard human $s F c \in R I I$ was collected and purified from the supernatant of RPMI 8866 cells (23).

Absolute number of $F c \in R I I(+)$ lymphocytes. The procedure to determine the percentage of FceRII(+) PBL was described previously (31). Briefly, heparinized blood was incubated with silica particles (KAC2, Japan Immunoresearch Laboratories, Takasaki, Japan) to remove monocytes/phagocytes. MNC were obtained by centrifugation over Ficoll-Paque (Pharmacia) (34). MNC were incubated with $20 \mu \mathrm{l}$ of $20 \mu \mathrm{g} / \mathrm{ml} \mathrm{H} 107$ antibody (first incubation), and then with $20 \mu \mathrm{l}$ of $20 \mu \mathrm{g} / \mathrm{ml}$ FITCconjugated anti-mouse IgG antibody (Tago Inc., Burlingame, CA) (second incubation) at $4^{\circ} \mathrm{C}$ for $30 \mathrm{~min}$. A negative control for each sample was prepared by the same procedure except that $20 \mu \mathrm{l}$ of $20 \mu \mathrm{g} / \mathrm{ml}$ non-related purified mouse myeloma IgG2b protein (Miles Scientific, Naperville, IL), which is the same class as the $\mathrm{H} 107$ antibody, was used at the first incubation instead of the $\mathrm{H} 107$ antibody. The percentage of fluorescence-positive cells in the lymphocyte population was determined by flow cytometry (FACS 440, Becton Dickinson Labware, Mountain View, CA). The difference in the percentage of fluorescence-positive cells between the sample and each negative control sample was re- corded as the percentage of $F c \in R I I(+)$ cells. The absolute number of $F c \in \operatorname{RII}(+)$ peripheral blood lymphocytes was calculated by the equation

Absolute

$\begin{aligned} & \text { number } \\ & \text { of } F c \in R I I(+)=\text { count }\end{aligned} \times \begin{aligned} & \text { Percentage of } \\ & \text { lymphocytes }\end{aligned}$ $\underset{\text { lymphocytes }}{\text { of } \epsilon \text { RII }(+)}=\underset{\left(1 / \mathrm{mm}^{3}\right)}{\text { count }} \times \underset{/ 100}{\left(1 / \mathrm{mm}^{3}\right)} \times \underset{\text { lymphocytes }}{ } \times$

$\left(1 / \mathrm{mm}^{3}\right)$

Percentage of $\mathrm{Fc} \epsilon \mathrm{RII}(+)$ lymphocytes $/ 100$

Analysis of data. Data on the serum $s F c \in$ RII were presented as the mean $\pm 1 \mathrm{SD}$. Data on the serum $\operatorname{IgE}$ were first transformed logarithmically, and then presented as the geometric mean and a range of 1 SD (28). The statistical significance of the difference in serum $s F c \in R I I$ levels was evaluated by a $t$-test. The statistical significance of the difference in serum $\mathrm{IgE}$ levels and the absolute number of Fc $\epsilon$ RII $(+)$ lymphocytes was evaluated by Wilcoxon's rank-sum test. The correlation of serum $s F c \in R I I$ and serum IgE levels or the absolute number of FceRII(+) lymphocytes was evaluated by rs. For convenience in calculation, serum IgE levels lower than $1 \mathrm{IU} / \mathrm{ml}$ were all approximated at $0.5 \mathrm{IU} /$ $\mathrm{ml}$.

\section{RESULTS}

Serum level of $s F c \in R I I$. The serum level of $s F c \in R$ II varies considerably with age in both allergic and nonallergic children. It was highest in infants and decreased gradually with age, reaching the adult level at about 8 y of age and then remaining constant. For statistical purposes, children were divided into four age groups, I, II, III, and IV, aged $<1,1-2,3-7$, and $8-15 y$, respectively (Table 1). The mean $\pm 1 \mathrm{SD}$ of age in allergic and nonallergic group I was $5.0 \pm 2.3$ and $4.5 \pm 3.3 \mathrm{mo}$, respectively.

Allergic children in groups I and II had significantly higher

Table 1. Serum sFceRII in allergic and nonallergic individuals (mean $\pm 1 S D$ )

\begin{tabular}{|c|c|c|c|}
\hline Age group & $\begin{array}{c}\text { Allergic } \\
(\mathrm{pg} / \mathrm{ml}) \\
(n)\end{array}$ & $\begin{array}{l}\text { Nonallergic } \\
(\mathrm{pg} / \mathrm{ml}) \\
(n)\end{array}$ & $p$ \\
\hline Cord blood & & $\begin{array}{c}479.1 \pm 199.2 \\
(11)\end{array}$ & \\
\hline I $\quad(<1 \mathrm{y})$ & $\begin{array}{c}1128.0 \pm 323.8 \\
(10)\end{array}$ & $\begin{array}{c}777.3 \pm 227.0 \\
(13)\end{array}$ & $<0.01$ \\
\hline II $\quad(1-2 y)$ & $\begin{array}{c}851.8 \pm 270.0 \\
\text { (11) }\end{array}$ & $\begin{array}{c}579.4 \pm 197.1 \\
(9)\end{array}$ & $<0.05$ \\
\hline III $\quad(3-7$ y) & $\begin{array}{c}586.3 \pm 194.6 \\
(8)\end{array}$ & $\begin{array}{c}510.6 \pm 183.2 \\
(9)\end{array}$ & NS \\
\hline IV $(8-15 y)$ & $\begin{array}{c}337.5 \pm 43.2 \\
(8)\end{array}$ & $\begin{array}{c}360.5 \pm 122.2 \\
(10)\end{array}$ & NS \\
\hline Adults & $\begin{array}{c}278.1 \pm 69.0 \\
(8)\end{array}$ & $\begin{array}{c}313.9 \pm 145.5 \\
(9)\end{array}$ & NS \\
\hline
\end{tabular}

Table 2. Serum IgE in allergic and nonallergic individuals (geometric mean and range of $1 S D$ )

\begin{tabular}{|c|c|c|c|}
\hline Age group & $\begin{array}{c}\text { Allergic } \\
(\mathrm{IU} / \mathrm{ml}) \\
(n)\end{array}$ & $\begin{array}{l}\text { Nonallergic } \\
(\mathrm{IU} / \mathrm{ml}) \\
(n)\end{array}$ & $p$ \\
\hline I $\quad(<1$ y) & $\begin{array}{c}14.1(1.8-112.2) \\
(10)\end{array}$ & $\begin{array}{c}0.8(0.4-1.7) \\
(13)\end{array}$ & $<0.01$ \\
\hline II $\quad(1-2 y)$ & $\begin{array}{c}120.2(25.1-575.4) \\
(11)\end{array}$ & $\begin{array}{c}3.9(0.9-17.0) \\
(9)\end{array}$ & $<0.01$ \\
\hline III $\quad(3-7 y)$ & $\begin{array}{c}776.2(331.1-1819.7) \\
(8)\end{array}$ & $\begin{array}{c}26.9(4.4-166.0) \\
(9)\end{array}$ & $<0.01$ \\
\hline IV $(8-15 y)$ & $\begin{array}{c}446.7(169.8-1174.9) \\
(8)\end{array}$ & $\begin{array}{c}38.9(7.4-204.2) \\
(9)\end{array}$ & $<0.01$ \\
\hline Adults & $\begin{array}{c}371.5(100.0-1380.4) \\
(8)\end{array}$ & $\begin{array}{c}85.1(21.9-331.1) \\
(9)\end{array}$ & $<0.05$ \\
\hline
\end{tabular}


Table 3. Percentage and absolute number of $F c \in R I I(+)$ peripheral blood lymphocytes in children (mean $\pm 1 S D$ )

\begin{tabular}{|c|c|c|c|c|}
\hline Age group & & Allergic & Nonallergic & \\
\hline I $\quad(<1 y)$ & $\begin{array}{l}\mathrm{N}^{*} \\
\% \dagger \\
n\end{array}$ & $\begin{array}{c}429.8 \pm 256.0 \\
7.3 \pm 1.5 \\
8\end{array}$ & $\begin{array}{c}256.2 \pm 47.0 \\
4.9 \pm 1.3 \\
6\end{array}$ & $\begin{array}{l}p<0.05 \\
p<0.05\end{array}$ \\
\hline II $\quad(1-2 y)$ & $\begin{array}{l}\mathrm{N} \\
\% \\
n\end{array}$ & $\begin{array}{c}369.2 \pm 119.4 \\
8.9 \pm 2.7 \\
10\end{array}$ & $\begin{array}{c}181.4 \pm 70.1 \\
4.3 \pm 1.4 \\
7\end{array}$ & $\begin{array}{l}p<0.01 \\
p<0.01\end{array}$ \\
\hline III $\quad(3-7 y)$ & $\begin{array}{l}\mathrm{N} \\
\% \\
n\end{array}$ & $\begin{array}{c}139.5 \pm 111.9 \\
5.9 \pm 2.1 \\
6\end{array}$ & $\begin{array}{c}127.5 \pm 65.9 \\
4.2 \pm 1.6 \\
6\end{array}$ & $\begin{array}{l}\text { NS } \\
\text { NS }\end{array}$ \\
\hline IV $(8-15 y)$ & $\begin{array}{l}\mathrm{N} \\
\% \\
n\end{array}$ & $\begin{array}{c}89.4 \pm 52.7 \\
4.4 \pm 1.8 \\
9\end{array}$ & $\begin{array}{c}90.8 \pm 40.7 \\
4.8 \pm 1.3 \\
12\end{array}$ & $\begin{array}{l}\text { NS } \\
\text { NS }\end{array}$ \\
\hline
\end{tabular}

* Absolute number of FceRII(+) lymphocytes $\left(1 / \mathrm{mm}^{3}\right)$.

$\dagger$ Percentage of FceRII(+) lymphocytes (\%).
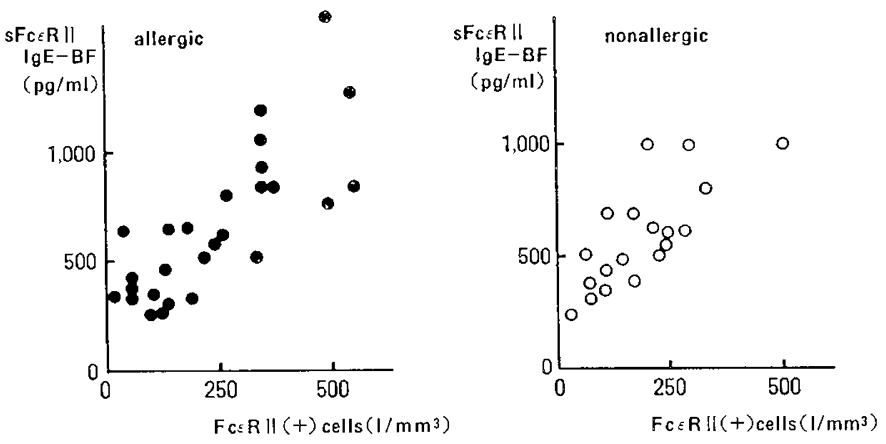

Fig. 1. Correlation of serum $s F c \in R I I$ and absolute number of $F_{C} \in \operatorname{RII}(+)$ lymphocytes. The serum $s F c \in R I I$ showed a close correlation with the absolute number of $\mathrm{Fc} \in \mathrm{RII}(+)$ lymphocytes in both allergic $($ left $)(\mathrm{rs}=0.79, p<0.001)$ and nonallergic children $($ right $)(\mathrm{rs}=0.72, p$ $<0.001)$.

levels of serum $\mathrm{sFc} \epsilon \mathrm{RII}$ than their nonallergic counterparts ( $p<$ 0.01 and 0.05 , respectively) (Table 1 ). However, significant differences in the serum levels of $s F c \in R I I$ between allergic and nonallergic individuals were no longer observed in groups III and IV or in adults.

The serum $s F c \epsilon$ RII was not affected by sex, medication with anti-allergic or anti-asthmatic agents, or type or severity of diseases (data not shown).

Correlation of $s F c \in R I I$ with serum IgE. The serum level of IgE in allergic children was significantly higher than in nonallergic children in all age groups (Table 2).

Generally, the correlation between the serum levels of $s F c \in R I I$ and of IgE was poor. The serum level of $s F c \in R I I$ tended to correlate negatively rather than positively with the serum level of IgE in both allergic and nonallergic individuals.

However, in allergic group I, three children, who had serum sFc $\epsilon$ RII levels higher than the mean $+1 \mathrm{SD}(1451.8 \mathrm{pg} / \mathrm{ml})$, also had significantly higher serum $\mathrm{IgE}$ (mean $125.9 \mathrm{IU} / \mathrm{ml} ; 1 \mathrm{SD}$ range $31.6-501.2 \mathrm{IU} / \mathrm{ml}$ ) than the other seven children $(5.6 \mathrm{IU} /$ $\mathrm{ml} ; 1.2-26.3 \mathrm{IU} / \mathrm{ml}: p<0.05)$.

Correlation of serum $s F C \in R I I$ with absolute number of $F C \in R I I+) P B L$. In nonallergic children, although the percentage of $F_{C} \in \mathrm{RII}(+)$ PBL was constant in all age groups, their absolute number showed a marked age-dependent variation similar to that of serum $s F c \in R I I$ (Table 3 ). It was highest in infants, and thereafter decreased with age. Both the absolute number of Fc $\epsilon$ RII(+) lymphocytes and the percentage of Fc $\epsilon$ RII(+) lymphocytes were significantly higher in allergic children of groups I and
II than in their nonallergic counterparts $(p<0.05$ and $<0.01$, respectively), whereas there was no significant difference between allergic and nonallergic children of groups III and IV (Table 3). The absolute lymphocyte count did not differ significantly between allergic and nonallergic children in each age-group (data not shown).

The relationship between the serum level of $s F c \in R I I$ and the absolute number off FceRII(+) lymphocytes was analyzed in 27 allergic and 19 nonallergic children. As shown in Figure 1, a significant positive correlation was demonstrated in both allergic and nonallergic individuals ( $\mathrm{rs}=0.79, p<0.001$ in the allergic and $\mathrm{rs}=0.72, p<0.001$ in the nonallergic).

\section{DISCUSSION}

The serum level of $s F c \in R I I$ showed a marked age-dependent variation in both allergic and nonallergic children and had a close positive correlation with the absolute number of FceRII(+) lymphocytes. Because the percentage of FceRII(+) cells in PBL is constant irrespective of age, except in allergic younger children (Table 3), the age-dependent variation of the absolute number of $F c \in R I I(+)$ lymphocytes is likely to reflect the total lymphocyte count. Therefore, the age-dependent variation of serum $s F c \in R I I$ of nonallergic children as well as of allergic older children may be due mainly to the physiologic age-dependent variation of the absolute number of lymphocytes. However, the increase in the serum level of $s F c \in R I I$ and in the absolute number of Fc $\epsilon$ RII(+) lymphocytes in allergic younger children is due not to an increase in the total number of lymphocytes but to the increased percentage of FceRII(+) lymphocytes (Table 3 ).

Fc $\in$ RII are expressed not only on lymphocytes, but also on monocytes/macrophages, eosinophils, and platelets (35-37). Inasmuch as most $\mathrm{sFc} \epsilon \mathrm{RII}$, if not all, is a degradation product of cell surface Fc $\epsilon$ RII $(15,26,27)$, blood cells other than lymphocytes may also release $s F c \in R I I$ into the serum. However, because the pattern of the age-dependent variation of lymphocytes is unique to them and different from that of the other blood cells (38), it appears that Fc $\epsilon$ RII(+) blood cells other than lymphocytes do not influence significantly the serum level of $\mathrm{sFc} \in \mathrm{RII}$; i.e., most of the serum $s F c \in R I I$ is probably derived from $\operatorname{Fc} \in \operatorname{RII}(+)$ lymphocytes.

Although two functionally different IgE-BF, IgE-potentiating and IgE-suppressive factor, were noted in a rodent model for IgE synthesis $(2,3)$, only IgE-potentiating activity is described for human IgE-BF derived from $\mathrm{Fc} \in \mathrm{RII}(+) \mathrm{B}$ cells $(13,14)$. Because most FceRII(+) PBL are B cells (31), the majority of serum $\mathrm{sFc} \epsilon \mathrm{RII}$ may be a product of $\mathrm{Fc} \epsilon \mathrm{RII}(+) \mathrm{B}$ cells. Therefore, serum $s F c \in R I I$ is assumed to be an IgE-potentiating factor. Generally speaking, however, serum $s F c \in R I I$ did not correlate with the serum IgE level. Although one of the most remarkable features of the serum level of $s F c \epsilon$ RII is its age-dependent variation, it did not resemble that of the serum IgE level. Moreover, no significant difference of serum $s F c \in R I I$ between allergic and nonallergic individuals of older age-groups was observed despite the significant difference of the serum $\operatorname{IgE}$ level. These results indicate that all serum $\mathrm{sFc} \epsilon \mathrm{RII}$ cannot be an IgE-potentiating factor. $s F c \in R I I$ may consist of multiple components with different functions, as has been shown in rodents $(2,3)$.

However, the biologic significance of $s F c \in R I I$ cannot be denied entirely because the serum levels of $s F c \epsilon R I I$ and of $I g E$ in allergic younger children (age groups I and II) were significantly higher than in nonallergic younger children. Moreover, in allergic group $\mathrm{I}$, children with very high levels of serum sFc $\epsilon$ RII also had significantly higher serum IgE levels than the other children. These findings suggest that $s F c \in R I I$ is related in some way to increased IgE synthesis, at least in younger allergic children.

The reason for the elevation of serum $s F c \in R I I$ in allergic younger children only is unknown. However, it is not diseaserelated because in group II (1-2 y) seven children had atopic dermatitis, two had bronchial asthma and two had both; their 
serum levels of $\mathrm{sFc} \epsilon$ RII were $861.4 \pm 272.5,885.0 \pm 365.0$, and $785.0 \pm 45.0 \mathrm{pg} / \mathrm{ml}$, respectively.

Recently, some lymphokines, such as IL- 4 and IFN- $\gamma$ have attracted attention as regulatory factors not only of the expression of Fc $\epsilon$ RII or the release of $s F c \in R I I$ but also of the $\operatorname{IgE}$ synthesis itself $(22,39-42)$; IL-4 enhances and IFN- $\gamma$ suppresses these reactions. The serum level of $s F c \in R I I$ as well as that of $\operatorname{IgE}$ might be affected by these lymphokines. However, we have little knowledge about the behavior of these lymphokines in allergic and nonallergic children, although the inability of $T$ cells to produce IFN- $\gamma$ has been noted in neonates $(43,44)$. Advances in the study of these lymphokines, as well as of $s F c \in R I I$, may provide a solution to this problem.

The elevation of serum $s F c \in R I I$ in allergic younger children seems to be determined congenitally to some extent. In a study which aims to pinpoint neonates at high risk for developing atopic diseases by the serum level of $s F c \in R I I$ in cord blood, our preliminary data show that infants who later develop atopic symptoms have a significantly higher cord serum $\mathrm{sFc} \epsilon$ RII than those who remain free of atopic symptoms $(593.7 \pm 334.4 \mathrm{vs}$ $393.8 \pm 174.8, p<0.01$ at 7 mo of age) (Kim KM, et al. unpublished data).

The measurement of serum IgE is an important laboratory test in the diagnosis of allergic disorders. However, in younger children the serum IgE level is often too low to be detected by routine assay systems. On the contrary, $s F c \in R I I$ is easily measured even in cord blood. For clinical purposes, serum sFc $\epsilon$ RII, along with other tests, may prove to be of value in diagnosing allergic disorders in early childhood.

Acknowledgments. The authors thank Drs. Takumi Kawabe and Masaya Hosoda, at the Institute for Immunology, Kyoto University, for generous guidance and help in measuring the serum sFceRII, and Drs. Yasuhiro Inoue, Yasusi Uenoyama, and Kouzou Mutoh, the Department of Pediatrics, Kyoto University, and Dr. Mitsuo Kaneshima, the Department of Gynecology, Yasaka Hospital, Kyoto, Japan, for help in collecting serum samples.

\section{REFERENCES}

1. Yodoi J, Ishizaka K 1980 Lymphocytes bearing Fc receptors for IgE. IV. Formation of IgE-binding factor by rat $\Upsilon$ lymphocytes. J Immunol 124:13221329

2. Suemura M, Yodoi J, Hirashima M, Ishizaka K 1980 Regulatory role of IgEbinding factors from rat $T$ lymphocytes. I. Mechanism of enhancement of $\mathrm{IgE}$ response by $\mathrm{IgE}$-potentiating factor. $J$ Immunol 125:148-154

3. Hirashima M, Yodoi J, Ishizaka K 1980 Regulatory role of IgE-binding factors from rat $\mathrm{T}$ lymphocytes. III. IgE-specific suppressive factor with IgE-binding activity. J Immunol 125:1442-1448

4. Yodoi J, Hirashima M, Ishizaka K 1980 Regulatory role of IgE-binding factors from rat $\mathrm{T}$ lymphocytes. II. Cycloprotein nature and source of IgE-potentiating factor. J Immunol 125:1436-1442

5. Yodoi J, Hirashima M, Ishizaka K 1981 Lymphocytes bearing Fc receptors for IgE. V. Effect of tunicamycin on the formation of IgE-potentiating and IgEsuppressive factor by Con A-activated lymphocytes. J Immunol 126:877882

6. Hirashima M, Yodoi J, Ishizaka K 1980 Regulatory role of IgE-binding factors from rat $\mathrm{T}$ lymphocytes. IV. Formation of IgE-binding factors in rats treated with complete Freund's adjuvant. J Immunol 125:2154-2160

7. Young MC, Leung DYM, Geha RS 1984 Production of IgE-potentiating factor in man by $\mathrm{T}$ cell lines bearing Fc receptors for IgE. Eur J Immunol 14:871878

8. Huff TF, Jardieu P, Ishizaka K 1986 Regulatory effects of human IgE-binding factors on the IgE response of rat lymphocytes. J Immunol 136:955-962

9. Yanagihara Y, Kajiwara K, Kiniwa M, Kamisaki T, Yui Y, Shida T, Delespesse G 1987 Modulation of IgE-synthesis by IgE-binding factors released by T cells of asthmatic patients with elevated serum $\mathrm{IgE}$. Microbiol Immunol 31:261-274

10. Nutman TB, Delespesse G, Sarfati M, Volkman DJ 1987 T cell-derived IgEbinding factors. I. Cloned and transformed $T$ cells producing IgE-binding factors. J Immunol 139:4049-4054

11. Gonzalez-Molina A, Spiegelberg HL 1977 A subpopulation of normal human peripheral B lymphocytes that bind IgE. J Clin Invest 59:616-624

12. Delespesse G, Sarfati M, Rubio-Trujillo M, Wolowiec T 1986 IgE receptors on human lymphocytes. II. Detection of cells bearing IgE receptors in unstimulated mononuclear cells by means of a monoclonal antibody. Eur J Im- munol 16:815-821

13. Sarfati M, Rector E, Wong K, Rubio-Trujillo M, Sehon AH, Delespesse G 1984 In vitro synthesis of IgE by human lymphocytes. II. Enhancement of the spontaneous IgE synthesis by IgE-binding factors secreted by RPMI 8866 lymphoblastoid B cells. Immunology 53:197-205

14. Sarfati M, Rector E, Rubio-Trujillo M, Wong K, Sehon AH, Delespesse G 1984 In vitro synthesis of IgE by human lymphocytes. III. IgE-potentiating activity of culture supernatants from Epstein-Barr virus (EBV) transformed $B$ cells. Immunology 53:207-214

15. Kawabe T, Takami M, Hosoda M, Maeda Y, Sato S, Mayumi M, Mikawa H, Arai K, Yodoi $J 1988$ Regulation of $F c \in R 2 / C D 23$ gene expression by cytokines and specific ligands ( $\operatorname{IgE}$ and anti-Fce $\mathrm{R}$ monoclonal antibody); variable regulation depending on the cell types. J Immunol 141:1376-1382

16. Rector E, Nakajima T, Rocha C, Duncun D, Lestourbgeon D, Mitchell RS, Fisher J, Sehon AH, Delespesse G 1985 Detection and characterization of monoclonal antibodies specific to IgE receptors on human lymphocytes by flow cytometry. Immunology 55:481-488

17. Suemura M, Kikutani H, Barsumian EL, Hattori Y, Kishimoto S, Sato R, Maeda A, Nakamura H, Owaki H, Hardy RR, Kishimoto T 1986 Monoclonal anti-Fc $\epsilon$ receptor antibodies with different specificities and studies on the expression of $\mathrm{Fc} \epsilon$ receptors on human $\mathrm{B}$ and $\mathrm{T}$ cells. J Immunol 137:1214-1220

18. Noro N, Yoshioka A, Adachi M, Yasuda K, Masuda T, Yodoi J 1986 Monoclonal antibody (H107) inhibiting $\mathrm{IgE}$ binding to $\mathrm{Fc} \in \mathrm{R}(+)$ human lymphocytes. J Immunol 137:1258-1263

19. Bonnefoy J-Y, Aubry J-P, Peronne C, Wijdenes J, Banchereau J 1987 Production and characterization of a monoclonal antibody specific for the human lymphocyte low affinity receptor for IgE: CD23 is a low affinity receptor for IgE. J Immunol 138:2970-2978

20. Huff TF, Yodoi J, Uede T, Ishizaka K 1984 Presence of an antigenic determinant common to rat IgE-potentiating factor, IgE-suppressive factor, and Fce receptors on T and B lymphocytes. J Immunol 132:406-412

21. Sarfati M, Nutman T, Fonteyn C, Delespesse G 1986 Presence of antigenic determinants common to $\mathrm{Fc}$ IgE receptors on human macrophages, $\mathrm{T}$ and B lymphocytes and IgE-binding factors. Immunology 59:569-575

22. Kikutani H, Inui S, Sato R, Barsumian EL, Owaki H, Yamasaki K, Kaisho T, Uchibayashi N, Hardy RR, Hirano T, Tsunasawa S, Sakiyama F, Suemura M, Kishimoto T 1986 Molecular structure of human lymphocyte receptor for immunoglobulin E. Cell 47:657-665

23. Ikuta K, Takami M, Kim CW, Honjo T, Miyoshi T, Tagaya Y, Kawabe T, Yodoi J 1987 Human lymphocyte Fc receptor for IgE: Sequence homology of its cloned cDNA with animal lectins. Proc Natl Acad Sci USA 84:819823

24. Lüdin C, Hofstetter H, Sarfati M, Levy CA, Suter U, Alaimo D, Kilchherr E, Frost H, Delespesse $G 1987$ Cloning and expression of the cDNA coding for a human lymphocyte IgE receptor. EMBO J 6:109-114

25. Yukawa K, Kikutani H, Owaki H, Yamasaki K, Yokota A, Nakamura $H$, Barsumian EL, Hardy RR, Suemura M, Kishimoto T 1987 A B cell-specific differentiation antigen, CD23, is a receptor for $\operatorname{IgE}(\mathrm{F} c \in \mathrm{R})$ on lymphocytes. J Immunol 138:2576-2580

26. Nakajima T, Sarfati M, Delespesse G 1987 Relationship between human IgEbinding factors (IgE-BF) and lymphocyte receptors for IgE. J Immunol 139:848-854

27. Sarfati M, Nutman TB, Suter U, Hofstetter H, Delespesse G 1987 T cellderived IgE-binding factors. II. Purification and characterization of IgEbinding factors produced by human $\mathrm{T}$ cell leukemia/lymphoma virus-1transformed T lymphocytes. J Immunol 139:4055-4060

28. Johansson SGO 1967 Raised levels of a new immunoglobulin class (IgND) in asthma. Lancet 2:951-953

29. Spiegelberg HL, O'Conner RD, Simon RA, Mathison DA 1979 Lymphocytes with immunoglobulin $\mathrm{E} F \mathrm{C}$ receptors in patients with atopic disorders. J Clin Invest 64:714-720

30. Nagai T, Adachi M, Noro N, Yodoi J, Uchino H 1985 T and B lymphocytes with immunoglobulin $F$ Fc receptors $(F c \in R$ ) in patients with nonallergic hyperimmunoglobulinemia $E$ : demonstration using a monoclonal antibody against FceR-associated antigen. Clin Immunol Immunopath 35:261-275

31. Kim K-M, Tanaka M, Iwai Y, Ito S, Mayumi M, Shinomiya K, Mikawa H $1988 \mathrm{lgE}$ receptor-bearing lymphocytes in allergic and nonallergic children. Pediatr Res 24:254-257

32. Yodoi J, Hirashima M, Ishizaka K 1981 Lymphocytes bearing Fc receptors for IgE. VI. Suppressive effect of glucocorticoids on the expression of Fct receptors and the nature of IgE-binding factors. J Immunol 127:471-476

33. Kim K-M, Tanaka M, Yoshimura Y, Katamura K, Mayumi M, Mikawa $H$ 1987 Regulation of IgE receptor expression on human peripheral blood lymphocytes by lymphocytosis promoting factor (LPF), lectins and dexamethasone. Clin Exp Immunol 68:418-426

34. Böyum A 1968 Separation of leukocytes from blood and bone marrow. Scand J Clin Lab Invest 21(suppl 97):77-89

35. Melewicz FM, Plummer JM, Spiegelberg HL 1982 Comparison of the Fc receptor for $\mathrm{IgE}$ on human lymphocytes and monocytes. J Immunol 129:563-569

36. Jouault T, Capron M, Balloul J-M, Ameisen J-M, Capron A 1988 Quantitative and qualitative analysis of the $\mathrm{Fc}$ receptor for $\mathrm{IgE}$ ( $\mathrm{Fc} \in \mathrm{RII}$ ) on human eosinophils. Eur J Immunol 18:237-241

37. Joseph M, Auriault C, Capron A, Vorng H, Viens P 1983 A new function for platelets: IgE-dependent killing of schistosomes. Nature 303:810-812

38. Miller DR 1984 Normal values and examination of the blood: perinatal period, 
infancy, childhood and adolescence. In: Miller DR, Baehner RL, McMillan CW (eds) Blood Diseases of Infancy and Childhood. CV Mosby Company, St Louis, pp 22-44

39. Defrance T, Aubry J-P, Rousset F, Vanbervliet B, Bonnefoy JY, Arai N, Takebe Y, Yokota T, Lee F, Arai K, De Vries J, Banchereau J 1987 Human reconbinant interleukin 4 induces Fce receptors (CD23) on normal human B lymphocytes. J Exp Med 165:1459-1467

40. Bonnefoy JY, Defrance T, Peronne C, Menetrier C, Rousset F, Pène J, De Vries JE, Banchereau J 1988 Human recombinant interleukin 4 induces normal $\mathrm{B}$ cells to produce soluble $\mathrm{CD} 23 / \mathrm{IgE}-$ binding factor analogous to that spontaneously released by lymphoblastoid B cell line. Eur J Immunol $18: 117-122$
41. Coffman RL, Carty J 1986 A T cell activity that enhances polyclonal IgE production and its inhibition by interferon $\gamma$. J Immunol 136:949-954

42. Prete GD, Maggi E, Parronchi P, Chrétien I, Tiri A, Macchia D, Ricci M, Banchereau J, De Vries J, Romagnani S 1988 IL-4 is an essential factor for the IgE synthesis induced in vitro by human $\mathrm{T}$ cell clones and their supernatants. J Immunol 140:4193-4198

43. Bryson YJ, Winter HS, Gard SE, Fisher TJ, Stiehm ER 1980 Deficiency of immune interferon production by leukocytes of normal newborns. Cell Immunol 55:191-200

44. Wakasugi N, Virelizier J-L 1985 Defective IFN- $\gamma$ production in the human neonate. I. Dysregulation rather than intrinsic abnormality. J Immunol 134:167-171 